'This article may not exactly replicate the final version published in the APA journal. It is not the copy of record.'

“To be a big shot or to be shot": Zing-Yang Kuo's other career

Geoffrey H. Blowers

University of Hong Kong

Hong Kong 


\begin{abstract}
The radical behaviourist Zing-Yang Kuo's other career reveals a figure who moved in the circles of senior university administrators and significant political figures. When he left China for Hong Kong after WWII, he did no more scientific research but embarked upon an autobiography and a study of Chinese national character. A chance renewal of his acquaintance with Leonard Carmichael led to the simultaneous publication of several papers based on work done in the 1930s, and thereby to the revival of his scientific reputation. But Kuo preferred to pursue his national character studies -- his only post WWII funded work -- in spite of briefly returning to America in the mid-60s to collaborate on a film of duck embryonic development. The author argues that it was the failure of his ambitions in China that led to both his interest in national character and to the revival of his scientific reputation, which might otherwise have lain dormant.
\end{abstract}

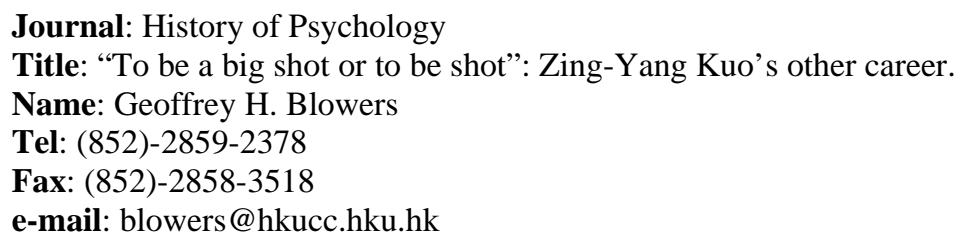




\title{
"To be a big shot or to be shot": Zing-Yang Kuo's other career"
}

\section{An American reputation}

\author{
Zing-Yang Kuo (a.k.a. Z.Y. Kuo, Kuo Zing-yang or Guo Renyuan²) is \\ remembered in the United States and in China as a radical behaviorist who wrote a \\ series of papers in the 1920s and 1930s, first as a student at Berkeley and subsequently in \\ several universities in China, condemning the use of the term "instinct" in psychological
}

\begin{abstract}
${ }^{1}$ Earlier versions of this paper were read at the XXX and XXXII Annual meetings of the International Society of the History of the Behavioral Sciences, held at the Universities of San Diego and Southern Maine, respectively. I am grateful to the following: Nadine Lambert, Barbara Glendenning of Tolman Hall Library, and Carol Soc, Assistant to the Dean of Studies, at the University of California, Berkeley, for their help in locating material relevant to Kuo's time there; Karen Ochsenhirt and John Popplestone, formerly of the Archives of the History of American Psychology, for Tolman and Macfarlane correspondence, and for access to restricted files of Kuo's personal correspondence; Lois Fischbeck, of the Archives of the American Philosophical Society for copies of Z.Y. Kuo materials from the Leonard Carmichael papers; David Hill of the Columbia University archives for confirming Kuo’s residency; Serena Yang and Ronda Cheung for their translations of Chinese source documents; Winston Hsieh of the Department of History, University of Missouri, Sun Longji, Department of History, Memphis State University, Alfred Lin, Department of History, HKU, Jing Qicheng of the Institute of Psychology, Academia Sinica, Al Fuchs of Bowdoin College, and Jacqueline Goodnow of Macquarrie University, who all shared their thoughts on Kuo; Gao Xiang for compiling documents, interpreting and co-ordinating various China visits; Yan Shifu of Fudan University for arranging an archival visit; Susan Xue Ying and Den Yu Ming of the Nanjing Second Historical Archives for making available files on the University of Nanjing; Zhou Maoqing and Yang Da Shou of Zhejiang University for sharing their thoughts on Kuo; Ma Jianhong of Hangzhou University for coordinating the visit. The staff of the Zhejiang Provincial Archives for making available documentation on Kuo's presidency at Zhejiang. Gilbert Gottlieb, Research Professor of Psychology at the Centre for Developmental Science, University of North Carolina for his early encouragement, recollections and helpfulness in steering me towards sources of interest; Don Dewsbury for being very helpful with background sources; Nancy Innis for sharing her insights on Tolman during Kuo’s Berkeley days; Tom Dalton for papers on the Kuo-Coghill debate; Jacqueline Goodnow for sharing her recollections of Kuo during her time in Hong Kong; Erik Kvan for his comments on an earlier draft and his unwavering support, and also, and most especially to the following members of Kuo's family for their reminiscences: Portia Sheen, Alex Kuo, KuoXiaoyuan, Ida Yu, and Mimi Cary. I am also very grateful for the early support offered in this project by Alex Kuo who granted me access to his late father's manuscripts.

2 The Chinese convention puts the family name first, and in the phonetic system of Kuo's day often hyphenated the second and third names with the third appearing in lower case. Nonetheless his name was spelled Kuo Jen Yuan, but he thought this would be too difficult for English readers to pronounce, and so adopted the idiosyncratic Kuo Zing Yang. China’s subsequent use of pinyin has meant that Kuo Zing Yang would today be spelt as ‘Guo Renyuan'. However, to avoid confusion for North American readers familiar with Kuo’s work, Kuo’s own spelling is retained throughout. For other familiar Chinese names in this text, both versions are given, the pinyin form appearing in brackets (and for towns appears in this form subsequently throughout).
\end{abstract}


explanation. ${ }^{3}$ During this period he also undertook a number of laboratory studies of the developing chick embryo, ${ }^{4}$ devised a technique for studying its maturational changes in vivo, ${ }^{5}$ and carried out a well-publicised experiment of rearing cats and mice together from birth to show they could act unaggressively towards each other. ${ }^{6}$ It was Kuo's thesis that the term "instinct" was a cloak for our ignorance of the subtle behavioural changes that accompany maturation. According to him, maturational change reveals at each and every turn a prior event eliciting the ongoing development, so that we need have no recourse to the term "innate mechanism" to explain the gradual unfolding of an organism's features. That a Chinese should jump on the "bandwagon of Watsonian behaviourism," as J.R. Kantor wrote in his obituary of Kuo, was because he had come from an entirely different cultural background, which made him "immune to the animistic nimbus that hovered over Euroamerican psychology." ${ }^{7}$ But by denying the

\footnotetext{
${ }^{3}$ Kuo, Z.Y. (1921) Giving up instincts in psychology. Journal of Philosophy, 18, 645-664. (1922) How are instincts acquired? Psychological Review, 29, 334-365. (1924) A psychology without heredity. Psychological Review, 31, 427-448. (1929) The net result of the anti-heredity movement in psychology. Psychological Review, 36, 1-35.

${ }^{4}$ Kuo, Z. Y. (1932a) Ontogeny of embryonic behaviour in aves: I. The chronology and general nature of the behaviour in the chick embryo. Journal of Experimental Zoology, 61, 395-430. (1932b) Ontogeny of embryonic behaviour in aves: II. The mechanical factors in the various stages leading to hatching. Journal of Experimental Zoology, 62, 453-487. (1932c) Ontogeny of embryonic behaviour in aves: III. The structural and environmental factors in embryonic behaviour. Journal of Comparative Psychology, 13, 245271. (1932d) Ontogeny of embryonic behaviour in aves: IV. The influence of embryonic movements upon behaviour after hatching. Journal of Comparative Psychology. 14, 109-121. (1932e) Ontogeny of embryonic behaviour in aves: V. The reflex concept in the light of embryonic behaviour in birds. Psychological Review 39, 499-515. (1933) Ontogeny of embryonic behaviour in aves: VI. Relation between heartbeat and the behaviour of the avian embryo. Journal of Comparative Psychology, 16, 379384.

${ }^{5}$ (1937a) Kuo, Z.Y. and Carmichael, L. Ontogeny of embryonic behaviour in aves: VII. A technique for the motion picture recording of the development of behaviour in the chick embryo. Journal of Psychology, 4, 343-348.

${ }^{6}$ Kuo, Z.Y. (1930) The genesis of the cat's responses to the rat. Journal of Comparative Psychology, 11, 135.

${ }^{7}$ Kantor, J.R. (1971) In memoriam: Zing Yang Kuo1898-1979 Psychological Record. 21, 361-383
} 
existence of instincts altogether, in McDougall's catchphrase, he “out-Watson[ed] Mr.

Watson." ${ }^{8}$

Kuo's work attracted a good deal of attention from the American scientific

community, ${ }^{9}$ so by the time he found it necessary to return to the United States in 1936,

he had a willing group of supporters, including his former Ph.D. supervisor Edward

Tolman, to help him find a tenured position there. He spent three years at Rochester,

Yale and the Carnegie Institute of Technology furthering his experimental studies, ${ }^{10}$ but

was unable to secure tenure and returned to China in 1940. By his own account, written

in the early 1950s, ${ }^{11}$ this move effectively ended his scientific career. And his

contributions might have slipped into obscurity had it not been for their championing

by two American scientists in the aftermath of the Second World War. Leonard

Carmichael, whom Kuo had befriended in the 1930s, was in an influential position as

head of the Smithsonian Institute in 1960 to secure publication of a number of Kuo's

studies undertaken in the 1930s. ${ }^{12}$ Gilbert Gottlieb invited him to collaborate on some of

\footnotetext{
${ }^{8}$ McDougall, W. (1921-1922) The use and abuse of instinct in social psychology, Journal of Abnormal and Social Psychology, 16, p.299.

${ }^{9}$ The responses to the first paper came from, Dunlap K. (1922) The identity of instinct and habit, Journal of philosophy, 19, 85-94, Geiger, J.R. (1922) Must we give up instincts in psychology?, Journal of philosophy, 19, 94-98, Hunter, W.S. (1922) The modification of instinct, Journal of philosophy, 19, 98101, McDougall, W. (1921-1922) The use and abuse of instinct in social psychology, Journal of Abnormal and Social Psychology, 16, 285-333, Tolman, E.C. (1922) Can instincts be given up in psychology?, Journal of Abnormal and Social Psychology, 17, 139-152, Wesley, R.W. (1921-1922) The value for social psychology of the concept of instinct, Journal of Abnormal and Social Psychology, 16, 334-343.

${ }^{10}$ (1937b) (with T.C. Shen) Ontogeny of embryonic behaviour in aves: X. Gastric movements of the chick embryo. Journal of Comparative Psychology, 21, 87-93 (1937c) (with T.C. R. Shen) Ontogeny of embryonic behaviour in aves: XI. Respiration in the chick embryo Journal of Comparative Psychology, 24, 49-58. (1938) Ontogeny of embryonic behaviour in aves: XII. Stages in the development of physiological activities in the chick embryo

${ }^{11}$ Kuo, Z.Y. "Confession of a Chinese Scientist" Unpublished manuscript, hereafter, Confession

${ }^{12}$ These papers, published with the help of Leonard Carmichael, (letter of Carmichael to Kuo, January 5th 1960) appeared in two consecutive issues of the Journal of Genetic Psychology as follows:

Kuo, Z.Y. (1960a) Studies on the basic factors in animal fighting: I. General analysis of fighting behaviour, The Journal of Genetic Psychology, 96, 201-206; (1960b) Studies on the basic factors in animal fighting: II. Nutritional factors affecting fighting behaviour in quails, The Journal of Genetic Psychology, 96, 207-216; (1960c) Studies on the basic factors in animal fighting: III. Hormonal factors affecting fighting in quail, The Journal of Genetic Psychology, 96, 217-223; (1960d) Studies on the basic factors in
} 
his studies in 1963 because he was interested in Kuo's technique for in vivo observation of duck embryos. It was Gottlieb who, following Kuo's death in 1970 in Hong Kong, persuaded the editorial board of the Journal of Comparative and Physiological Psychology to break with its policy of publishing only scientifically based articles and print an obituary of Kuo authored by Gottlieb himself. ${ }^{13}$ To this day this has been the major source by which others have come to know of Kuo's work.

Gottlieb became familiar with Kuo's work primarily through his 1960 papers published under Carmichael's auspices and his subsequent visit to Gottlieb's psychology lab at Raleigh, North Carolina. Carmichael on the other hand had met Kuo several times in the 1930s and early 1940s but then lost touch until the early 1950s. The period of Kuo's life between 1943 and 1954, after which correspondence between him and Carmichael ${ }^{14}$ resumed, has remained, for western commentators interested in Kuo, a mystery. There are however a few hints of his activities dropped in correspondence and in two manuscripts he wrote in the 1950s. One of these, called "Confession of a Chinese Scientist," gives an account of some of the activities of his professional life. The other entitled, "Chinese National Character and the Myth of Communism," is an analysis on how the Communists came to power in China. ${ }^{15}$ These documents, which remain unpublished, are nonetheless valuable for the picture they give us of Kuo's life outside

animal fighting: IV. Developmental and environmental factors affecting fighting in quails, The Journal of Genetic Psychology, 96, 225-239; (1960e) Studies on the basic factors in animal fighting: V. Inter-species co-existence in fish, The Journal of Genetic Psychology, 97, 181-194; (1960f) Studies on the basic factors in animal fighting: VI. Inter-species coexistence in birds, The Journal of Genetic Psychology, 97, 195-209; (1960g) Studies on the basic factors in animal fighting: VII. Inter-species co-existence in mammals, The Journal of Genetic Psychology, 97, 211-225;

${ }^{13}$ Gottlieb, G. (1972) Zing-Yang Kuo: radical scientific philosopher and innovative experimentalist (18981970). Journal of Comparative and Physiological Psychology, 80, No. 1, 1-10.

${ }^{14}$ The Kuo - Carmichael correspondence is housed in the Archives of the American Philosophical Society. 15 A copy of the Confession of a China Scientist" is lodged with the Archives of the American Philosophical Society. Kuo's son, Alex, kindly gave me a copy of "Chinese National Character and the Myth of Communism." 
of the laboratory. Taken together with the Carmichael correspondence and with archival documents in China and interviews with some people who knew him, it is possible to reconstruct some of the events that shaped Kuo's coming to be remembered as a leading China psychologist. ${ }^{16}$ As such this account departs from previous ones that have concentrated solely upon the scientific career or the status of his research findings to show Kuo in a new light. Although his scientific reputation was established quite early in his life, and on the basis of a research program which came to an end when he reached forty, it was enhanced by an ironic twist in the fortunes of his other career: that of a university administrator with political connections, and of a would-be ambassador.

\section{Return to China}

Kuo's administrative ambitions showed up rather early in his professional life. Having returned to China from Berkeley in 1923 where he completed work for his doctorate, and gained a reputation as a graduate with great intellectual promise, ${ }^{17}$ he took a teaching position at his alma mater, Futan (Fudan) University, in Shanghai. But within two years he had assumed the position of President of the University. He was only 26 years old. Soon after joining Fudan he had impressed the administration with

\footnotetext{
${ }^{16}$ See for example, Carl Degler In search of Human nature: the decline and revival of Darwinism in American social thought (New York: Oxford, 1991), P.C. Rodkin's A developmental, holistic futureoriented behaviorism: Kuo's The Dynamics of Behavior revisited. Contemporary Psychology 41, 10851086. Gilbert Gottlieb's, Zing Yang Kuo: Radical scientific philosopher and innovative experimentalist in G.A. Kimble and M. Wertheimer (Eds.) Portraits of Pioneers in Psychology III Washington, DC: American Psychological Association (1997), Mark Rilling's entry on "Kuo" for the Encyclopaedia of Psychology APA/OUP, 2000.

${ }^{17}$ At Berkeley he had been allowed to enter directly into the second year of the undergraduate program on the strength of his first year studies at Fudan University in Shanghai. He took courses in a number of subjects including Botany, Zoology, and German as a foreign language, but he majored in 1921 in Psychology with Philosophy and Education as his minor subjects. In Psychology he got top honours. By early 1923 he had already submitted his doctoral thesis entitled, "A behaviouristic experiment on inductive inference", and had completed four papers, three of which had been published, the other about to appear. He had also been writing a book in Chinese on psychology, which would find a publisher in Shanghai that same year under the title Renlei de Xingwei [Human Behaviour] Shanghai: Commercial Press. 1923.
} 
his ability to raise funds through his wealthy family connections. ${ }^{18}$ This had led to two buildings being erected, one devoted to psychology. When a temporary vacancy became available after the President was involved in a scandal over contracts, Kuo was asked to take over as acting-President. ${ }^{19}$ In his brief tenure as President he introduced a number of reforms. ${ }^{20}$

Kuo remained in this position until 1926, by which time the political situation in Shanghai became a source of concern for many, including him. The China he had left in 1919 and returned to in 1923 was one of great cultural upheaval and political uncertainty. The new republic, founded in 1912, had gotten off to a shaky start. After 1916, the revolutionary party of the Kuomintang - KMT (Guomindang) - strove to build its power in the South but most of the provinces were still ruled by warlords. Also, by 1921 a Communist party had been formed and was gaining converts. A coalition between these two parties occurred in the early 1920s ostensibly to strengthen the KMT by including those who had been able to draw on grass roots support among people not previously sympathetic to the dominant party. But by 1926 suspicions abounded amongst the Nationalists that the Communists had another agenda. As Chiang Kai-shek (Jiang Jieshi), by this time the leader of the KMT, marched north from his base of

\footnotetext{
${ }^{18}$ A distant cousin and his sons, wealthy family merchants, donated US\$200,000. Confession Ch. 4 "Of chicks, kittens and an unenviable career." See also note 99.

${ }^{19}$ Interview with Fudan University archivist, Shanghai, Oct. 22nd. 1998. According to Ch. 6 of Confession, "My Life as a College President", Kuo was offered the position on a temporary basis but would then be Vice President in charge of administration when the previous incumbent returned after a one or two year break.

${ }^{20}$ These included the adoption of an American style of grading degree by Grade Point Average (GPA) and the establishment of a College of Sciences, which included a department of psychology, and a Middle School in which high school students could enrol to learn about psychology while receiving a secondary education. He also introduced measures to encourage better study habits by deducting marks or threatening outright dismissal to students caught cheating. He was less successful in trying to stamp out the widespread habit of teachers moonlighting to supplement their incomes even though he offered higher salaries.
} 
operations in the south and descended on Shanghai in 1927, he struck against communist members in the coalition killing many in the process.

Kuo's own account of this period in the Confession raises the question of the extent to which he was politically active, particularly at this sensitive and crucial time. As he wrote, "Reluctantly I had to divide my time between the internal affairs of the university and outside activities to help save Shanghai from destruction by the Reds." ${ }^{21}$ These activities appear to have included helping to write anti-Communist propaganda with other like-minded educationalists. He was aware that many of his own students had political affiliations, but he generally tried to steer them to an open mindedness on the broader questions for which they had been admitted to the university to study in the first place. Like most Chinese of the period he was upset over the continued power exerted by foreigners in his country. For those educated abroad with qualifications as good as their foreign counterparts (if not better) this could be a humiliation. He describes in some detail how, as university President, he played a frustrating role in getting greater Chinese representation in an Athletics Association of several colleges most of which were dominated by American missionaries. In arranging these negotiations (which eventually led to the formation of a different Association and the removal of Fudan from the established one) he was anxious to avoid playing into the hands of Communists who would have seen the event not as a victory for Chinese nationalism, but as a means of infiltrating an influential student body to gain converts. ${ }^{22}$ Whether this action was construed by political observers of the period as a strike against the Communists one cannot be sure, but according to his own account, ${ }^{23}$ by late

${ }^{21}$ Confession Ch. 6 "My life as a College President".

${ }^{22}$ Confession Ch.7 "Shoot to kill"

${ }^{23}$ Confession, Ch.4 
1926, Kuo would appear to have had reason to fear the approach of the National

Revolutionary Army into Shanghai and resigned his post. ${ }^{24}$

For two years Kuo remained in self-imposed exile on a farm on the outskirts of

Shanghai while a significant battle waged in the city between different factions of the

Kuomintang army. In the ensuing chaos much of the campus was overrun and books,

labs and equipment were destroyed.$^{25}$ To support himself he wrote a number of

psychology texts and yet also carried out a series of observational studies of animal

fighting which were to remain unpublished for thirty years. ${ }^{26}$ In 1929 he received an

invitation from the President of the National University of Chekiang (Zhejiang), ${ }^{27}$ Chen

Tian Fang, ${ }^{28}$ to be a research professor there. ${ }^{29}$ Although it was a relatively brief period

in his otherwise trouble torn life, it was to be a remarkably fruitful one. ${ }^{30}$ It was the

\footnotetext{
${ }^{24}$ At the time of his resignation in September of 1926, the Northern expeditionary army, under its commander-in-Chief Chiang Kai-shek and Russian advisers, had begun it move northwards from its southern base in Kwangtung (Guangdong) and was involved in several campaigns leading them to take major cities in Hunan, Hupei, Kiangsi and Fukien provinces. Its primary objective, as stated in Chiang’s proclamation in Changsha that August, was "to liberate China from the warlords and win its rightful place of equality among nations with friendship for all.” This army however, in addition to being in alliance with the Communists, had several factions within it with differing aims and objectives. There were hard line sentiments on the left and right of the KMT expressing either a sympathy for, or antipathy to, both the alliance and the fact that many communists were actually occupying significant positions within the KMT itself. To further complicate matters these factions at this time were located in two different cities - the KMT left arm, plus their communist sympathisers in Wuhan, and Chiang's right and centre elements in Nanchang - in each of which their further offensives were separately planned. Since Shanghai was one of their targets, it was not clear in that September as to which wing of the army would take responsibility for the siege or when it would occur. See C. Martin Wilbur, (1986) The Nationalist Revolution: from Canton to Nanking, 1923-28 in D. Twitchett and J.K. Fairbank, The Cambridge History of China, Vol 12 part 1. p.547ff.

${ }^{25}$ Kuo considered going back to America for a year at this juncture and sought Tolman's help. Tolman tried Yerkes and Boring (letters of April 13th) but neither had a position available.

${ }^{26}$ See note 12 .

${ }^{27}$ In Hangchow (Hangzhou) situated about $180 \mathrm{~km}$ south of Shanghai.

${ }^{28}$ Like Kuo, Chen Tian Fang had gone to study in America after graduation from Fudan University in 1919, and moved to Toronto to do a PhD in Political Science. He returned to China with his doctorate completed in 1926. He held important posts including head of Education in Anhui and Hubei provinces, and Head of the Kuomintang's Central Promotion Department. In 1932 he was Vice President of Zhejiang University. From 1935 to 1938 he was ambassador to Germany. In 1949 he went to Taiwan and became Head of Education there. He died in New York in 1967. See Jia Jichu A brief History of Zhejiang

University p.224ff

${ }^{29}$ Confession, Ch. 4

${ }^{30}$ See notes 4 and 6 .
} 
period that saw him undertake a series of careful experimental studies of the embryological development of chicks. He also published a study that began as an idea he had originally suggested Hu Jinan -- one of his research students at Fudan -undertake: the effects on the cat's tendency to kill mice, of rearing kittens with mice. ${ }^{31}$ While no one had doubted that cats instinctively kill rats or mice in their natural environment, Kuo was interested in demonstrating what would happen under controlled laboratory conditions where cats and rats ${ }^{32}$ might be reared together. Kuo's studies demonstrated the difficulty of getting kittens reared with rats to kill them. "Our study has shown that kittens can be made to kill a rat, to love it, to hate it, or fear it or to play with it: it depends on the life history of the kitten...Our behaviour researches in the past have been in the wrong direction, because, instead of finding how we could build nature into the animal, we have tried to find nature in the animal 33 ... if one insists that the cat has an instinct to kill the rat, I must add that it has the instinct to love the rat too. In behaviour nature is what can be built in and not what is supposed to unfold from within." (p.35). ${ }^{34}$

In his own account, Kuo mentions that this again brought him some expected fame as the results were abstracted from the scientific journal in which it first appeared and reproduced in various newspaper articles in New York, Paris and Berlin. But he treated it as a digression. His most significant contribution to the field during this period was his invention of an in vivo method for observing developing embryos.

The problem of observing a live foetus in its sac (egg) is that it requires the removal of the inner and outer membranes which otherwise occlude the view. On

\footnotetext{
${ }^{31} \mathrm{Hu}$ 's own account mentions Kuo instructed him in the technique of raising kittens and mice together. Hu is not, however, credited in the paper that was eventually published in 1930 under Kuo's own name.

${ }^{32}$ Kuo's studies used albino rats, wild rats and dancing mice.

${ }^{33}$ Italics in the original.
} 
removing the inner membrane however, the contents of the egg are very likely to spill out and the unborn animal dies. Kuo had discovered a technique of partially removing the membranes but coating the gap created with a thin layer of Vaseline. This leaves the animal otherwise intact and, under careful conditions of incubation, development can proceed (and be observed). This was a considerable advance over earlier attempts to study embryos by either sectional observations (of removing embryos from their sacs at different period allowing their death but then studying them in a fixed state), or in looking at them through cut sacs covered with glass plates. In the latter state the animal might survive but its development proceeds in an unnatural environment from which the embryo is not immune. ${ }^{35}$

With this method, an imported incubator and what seemed like an unlimited supply of eggs, Kuo set out in a series of studies to verify his foundational position that behavioural development is a smooth, continual process from the beginning of the heartbeat to hatching. Much of this work was published in prestigious American journals. $^{36}$

However, in late 1931 Zhejiang University was in serious financial trouble. ${ }^{37}$ With Chiang Kai-shek leading troops in Kiangsi (Jiangshi) province in a campaign against the Communists, corruption in the capital, Nanking (Nanjing), was becoming widespread. The Japanese had invaded Manchuria. There was flooding in the Yangtze (Yangzi) basin. Salaries were long overdue. Kuo left to take up an honorary

\footnotetext{
${ }^{34}$ Kuo, Z.Y. (1930) The genesis of the cat's responses to the rat. Journal of Comparative Psychology, 11, 1-35.

${ }^{35}$ Confession. Ch. 4

${ }^{36}$ See note 4

${ }^{37}$ Confession, Ch. 4
} 
appointment at Nanjing University, which he held for about fifteen months, during which time Nanjing became the centre of great student unrest.

Kuo accepted an invitation from Chu Chia-hwa (Zhu Jiahua), the Minister of Education in the Nanjing Government, to be President of Zhejiang University, a position he took up on $20^{\text {th }}$ March $1933 .{ }^{38}$ But this time his tenure as a college President in which he again tried to introduce reforms was to be his undoing.

According to two sources, Zhou Maoqing ${ }^{39}$ - Zhejiang University Emeritus Professor of mathematics and a student on campus at the time of Kuo's presidency, and Jia Jichu's published history of Zhejiang University ${ }^{40}$ - Kuo's reforms proved very unpopular. He wanted all students to study electronics, which he thought a very important subject. He tried to instill discipline in the student body by treating them like army recruits and insisted they drilled, dress in uniform and, when walking in the street, salute each other. He was a remote figure not close even to his colleagues.

In 1935 the "12-9" movement occurred in response to Japanese incursions into eastern Hopei (Hebei) province, a previously demilitarised zone in the northwest part of China. (The numbers refer to the date - December $9^{\text {th }}$ - in which large-scale student demonstrations on many university campuses, particularly in Peking [Beijing] and Nanjing, broke out). Kuo's students wanted to go to Nanjing to join their fellow students in protest, but he did not permit this and locked the university gates. Many staff sympathetic to the students' cause were fired. Students started skipping classes, and the drive to remove Kuo began. The situation deteriorated rapidly and by winter of 1935

\footnotetext{
${ }^{38}$ Files of Zhejiang provincial archive. In his Confession (ch. 6) Kuo hints the appointment might have come through Chen Kuo-fu, a significant member of the "Central Club" which was an influential recruiting organisation to important posts within the Nationalist KMT party.

${ }^{39}$ Interview with Zhou Maoqing, Zhejiang University, December 15th 1999

${ }^{40}$ Jia Jichu (Ed.) A brief History of Zhejian University
} 
Kuo tried to press the Ministry of Education in Nanjing to support him. After Chiang Kai-shek visited the campus and spoke to the students, he decided to replace Kuo with Zhu Kezheng. ${ }^{41}$ Over 68 teachers had left during Kuo's presidency. Most of them were reinstated after Zhu's appointment. ${ }^{42}$

Kuo's lack of sympathy for his students' desire to protest foreign incursions into China, coupled with his strict regime of discipline, led to his administrative difficulties. As a KMT appointed college President, his tough stance towards them might have been motivated by his wish to appear capable in the eyes of senior officials in the Ministry of Education who were concerned that unrest on university campuses was fuelled in some instances by students sympathetic to the communist cause. ${ }^{43}$ Nonetheless, he had alienated himself from his colleagues and the student body. His situation at this time was grim, and he decided to leave Hangzhou and China altogether. ${ }^{44}$ By July of 1936, he was back in the United States renewing his connection to his former supervisor, Edward Tolman at Berkeley.

\section{Back to America}

Kuo remained at Berkeley for a semester while Tolman sought out his connections to get him placed more permanently. Because of the economic depression finances were generally lacking even though a number of people were otherwise helpful in offering laboratory space. More pressing was the matter of Kuo's Ph.D. When he left Berkeley in 1923 he had completed requirements for his doctorate but had not defended his thesis. This had been delayed because of a dispute that had arisen between the

\footnotetext{
${ }^{41}$ Ibid.

${ }^{42}$ Zhou Maoqing, op.cit.

${ }^{43}$ Jia Jichu op.cit. p.33ff
} 
psychology and philosophy members of his thesis committee over the nature of what constituted a thesis. The philosophers had insisted that Kuo provide a historical review but he refused to make amendments. Tolman was sympathetic. The case went to the Graduate Council, which supported the psychology department's position that no amendments were necessary. ${ }^{45} \mathrm{~A}$ date was set for the oral exam but Kuo, in the interim and against Tolman's advice, had left for China. In his subsequent university appointments in China he passed himself off as having received his doctorate, ${ }^{46}$ suggesting that, for him, his time in America had served its purpose and he would have no further need to return. His doctoral candidacy had lapsed in 1927. Finding himself back in the USA in 1936 seeking a tenured position meant having to reactivate his candidacy, which Tolman did. ${ }^{47}$

One of Tolman's contacts, Leonard Carmichael, then Head of psychology at the University of Rochester, invited Kuo for a semester. Carmichael had been impressed by Kuo's earlier work some of which he had incorporated into a review commissioned for Carl Murchison's Handbook of Child Psychology in 1933. Soon after Kuo and Carmichael met in July 1936, they became friends and their correspondence, although broken during the wars years and their immediate aftermath, was to last until Kuo's death in 1970. Like Tolman, Carmichael was to prove very useful to Kuo. Besides arranging some limited funding, a title and equipment, he supported Kuo's application for a Fellowship to

\footnotetext{
${ }^{44}$ Confession Ch. 4

${ }^{45}$ Minutes of the Graduate Council, Berkeley, February $23^{\text {rd }} 1923$.

${ }^{46}$ Fudan University's yearbook for 1923 (The Futan Monitor) has a photograph of Kuo with his name and the caption "PhD (Berkeley)" underneath.

${ }^{47}$ The exam was scheduled for November $12^{\text {th }} 1936$, but the thesis, which is housed in the Bancroft library at Berkeley, has only a copy of Kuo's published 1923 paper between its covers, and a cover sheet with the typewritten names of the revised committee. This article likely is about the same as the dissertation he submitted.
} 
undertake research at Yale's Osborn Zoological laboratory. ${ }^{48} \mathrm{He}$ and Kuo collaborated on making a film of his technique for studying chick embryos in vivo. ${ }^{49}$

While at Yale Kuo worked on a couple of studies investigating the CoghillWindel controversy over the relative effects of "total" as opposed to local movements and their relative effects on maturational development. ${ }^{50}$

Against the prevailing view of his day - that simple reflexes preceded and were the basis of later complex movements - George Coghill, working on embryonic development in the salamander, had posited that a pattern of "total response" preceded any developments of a "local segmented response" (his term for a reflex) i.e. local patterns become differentiated from earlier total patterns. ${ }^{51}$ Limbs for example, come to move only as the trunk moves. At a later stage they acquire independence. Coghill referred to this phenomenon as a forward reference implying that a certain level of development had to occur before any valid environmental stimulation would induce changes (learning effects). But at that time Coghill did not specifically consider his findings in these terms, which, as Oppenheim has pointed out, left his work open to many different interpretations. ${ }^{52}$

During the 1930s Kuo chose to interpret Coghill's work as unsubstantiated by evidence, meaning he did not, unlike Kuo himself, seek an entirely environmentalist explanation of his results. In the first two studies in his 1932 series carried out while still

\footnotetext{
${ }^{48}$ Psychological Bulletin, 1937, 34 p.499

${ }^{49}$ See note 5.

${ }^{50}$ Coghill, G.E. (1929) Anatomy and the problem of behaviour. New York: Hafner. See also, Coghill (1933) The neuroembryonic science of behaviour: principles, perspectives and aims. Science, 78, 131-138 and Coghill (1940) Early embryonic somatic movements in birds and mammals other than Man. Monographs of the Society for Research in Child Development, 5, No. 2 (serial 25).

51 Bergenn, V.W., Dalton, T.C. and Lipsitt, L.P. (1992) Myrtle B. McGraw: a growth scientist. Developmental Psychology 28, 381-395

52 Oppenheim, R. W. (1978) G.E. Coghill: (1872-1941): pioneer neuroembryologist and developmental psychobiologist. Perspectives in Biology and Medicine. Cited in Bergenn et al, Op.cit.
} 
in China, Kuo made no mention of Coghill's work. In his third study however, ${ }^{53}$ Kuo found fault with Coghill's explanation that it is a growth in neuronal activity that leads the salamander to start swimming. According to Kuo, Coghill's account stops short of including as likely causes the underlying physiological and metabolic changes that accompany structural changes in the neuronal system. From his own observations Kuo reasserted his position that behaviour should be seen as continuous and not as occurring at a particular moment. Kuo wanted to dispel what he saw as the shackles of the then prevalent theoretical language of instinct and trial-and-error learning. He saw these terms forming a dichotomy that impeded understanding. Kuo was to coin the alternative term which essentially dissolved this distinction - behaviour gradient - but it was to be another 35 years before it appeared in print.

Although Kuo impressed a number of his colleagues with his commitment and zeal he was unable to secure a tenure-track position ${ }^{54}$ and accepted he would have to go back to China, which the Japanese had invaded and were inflicting considerable devastation on the cities of its eastern seaboard. But, in a letter to Carmichael in March 1938 he wrote of being contacted by "a special envoy of the Chinese Government (not the ambassador)" who advised him, in view of the growing rift between the Chinese Communists and the KMT, to stay in America. But Kuo thought that if he did not go back at this time "he would not return after the war as [his] prestige and leadership [would] be gone forever." ${ }^{55}$

\footnotetext{
${ }^{53}$ Kuo, Z. Y. (1932c) Ontogeny of embryonic behaviour in aves: III. The structural and environmental factors in embryonic behaviour. Journal of Comparative Psychology, 13, 245-271

${ }^{54}$ George Streeter to Madison Bentley, March 14th, 1938.

${ }^{55}$ Kuo to Carmichael, March 1938 (date unknown)
} 
With Carmichael's support Kuo eventually obtained a grant from the Rockefeller Foundation enabling him to stay in the USA for one more year. ${ }^{56}$ He settled in George Streeter's lab at the Carnegie Institute in Washington. But his letters to Carmichael suggest he was restless, wanting to stay only long enough to write up his reports and wait to see what was transpiring back home. He joked in one letter he was not sure whether, by going back to China at this precarious time, he was "to be a big shot or to be shot." ${ }^{57}$ Nonetheless he did make a brief trip to China in early June of 1938, possibly for family reasons, and told Carmichael shortly after he returned to the USA six weeks later, "there was a big political job waiting for me when I arrived at Hankou and, of course, I smiled and said, 'Sorry, can't take it.'"'58

At the end of his tenure Kuo returned to China sometime in early summer of 1940. It is likely he was invited back by his former student Hu Jinan who was teaching at Fudan University, ${ }^{59}$ now evacuated to Chungking (Chongqing) in Szechwan province to escape the hostilities with the Japanese. ${ }^{60}$ Soon after arrival, he established a private physiological psychology institute with himself as Director. Carmichael, at Kuo's request, wrote asking John McGeoch and James Mckeen Cattell, editors of Psychological Bulletin $^{61}$ and Science respectively, to place announcements of this development in their

\footnotetext{
${ }^{56}$ Carmichael was later to say that one problem Kuo faced in getting tenure was his English, which "was not such that he could have been selected for undergraduate teaching in most American Universities" (letter of Carmichael to Gottlieb August 25th, 1971).

${ }^{57}$ Kuo to Carmichael April 29th 1938.

${ }^{58}$ Kuo to Carmichael July 30th 1938.

${ }^{59}$ See note 19.

${ }^{60}$ Many eastern seaboard universities and colleges were evacuated into the interior after 1938 following the continuing hostilities with the Japanese and their advance through the eastern regions. Some of these universities formed amalgamations in different regions. E.g. Nankai, Peking and Tsing Hua universities, initially evacuated to Changsha in Central China, went on to Yunan province in the South-west, to form the National South West Associated University, Kunming. Others went Northwest to form the National North West Associated University in Sian (Xian).

${ }^{61}$ Psychological Bulletin, 1941, 38, p.305
} 
journals (which they did). However, Kuo's leaving America at this juncture signified the end of his career as an active scientific researcher.

\section{China ambassador}

In late 1940 Kuo was living and working in Chungking, the city to which Chiang Kai-shek had moved his troops to launch his war operations against the Japanese invasion. Although he had set up a private research centre no published work from his time there emerged. He was soon writing again to Carmichael announcing he would be going on a lecture tour to England by way of America in the spring of 1941. Kuo arrived in America on $23^{\text {rd }}$ March that year. ${ }^{62}$ His mission had come from the Ministry of Education as an initiative to win friends abroad. His job was to contact University presidents with a view to seeing whether economic aid could be granted to more China students studying in the United States. His subsequent letters to Carmichael reflected his new role. After urging him to set up a meeting with some of the presidents of East Coast universities, Kuo reminded Carmichael of the importance of his visit. “Confidentially the mission has the $100 \%$ backing of the Generalissimo. He takes this matter seriously and told me that the government is ready at any time upon my recommendation to decorate any American education leaders who have worked hard to promote cultural cooperation between China and the U.S.A. The education minister and the president of Academia Sinica are among the closest associates of the Generalissimo, among those very few who are considered as 'inner circle' men of Chiang [Jiang]. They happen to be

${ }^{62}$ Science, 1941, 93, p.471 
my closest friends too. Between you and me this is a good chance for you to become internationally known as an educational leader." ${ }^{\prime 33}$

In spite of the bluster, Kuo's mission was intended by the Chungking Ministry of Education to be limited to securing greater economic aid from America and Britain for the training of larger numbers of China students in their universities. Carmichael arranged the contacts. As he had been working for the War Department on a "national roster of scientific and specialised personnel" ${ }^{\prime 4}$ by which he and a team of associates, using questionnaires and checklists, could ascertain the relative strength of people with different skills and training, Carmichael also suggested Kuo might like to acquire these instruments for the purposes of doing something similar in China. Carmichael's connections to the State Department would ensure their availability. Kuo subsequently incorporated this idea into his mission statements and, as the university Presidents he talked to warmed to the idea, this eventually evolved into a plan to form an American Council for Cultural Cooperation with China under the auspices of the State Department. Kuo had intended calling a conference to outline his plans but postponed it in order to go to Britain in September of $1941^{65}$ to read a paper at the British Association for the Advancement of Science, and to meet university leaders there. ${ }^{66}$ In this he was assisted by the Chinese ambassador to Britain, Wellington Koo (Gu Weijun), who also saw to it that he met with representatives of the British Council and the Federation of British Industries, and the Minister of Education, Richard Butler. Kuo returned to America in January the next year, and received a letter from Charles Thompson, the Chief of the Cultural Relations division of the State Department, informing him that they

\footnotetext{
${ }^{63}$ Kuo to Carmichael March 31st 1941

${ }^{64}$ Carmichael to Kuo February 21st 1941

${ }^{65}$ Psychological Bulletin, 1942, 39, p.196
} 
were contemplating "calling together representatives of various private organisations in this country interested in China, including universities, libraries, and foundations. ${ }^{167} \mathrm{It}$ seemed Kuo's project was being given serious consideration even without his having made a direct overture to the State department.

How this occurred is not altogether clear although in his Confession, written ten years after these events, Kuo indicated it had a good deal to do with what some in the Chinese political bureaucracy saw as his seriously overstepping the bounds of his appointed role and they may have sought to curtail him. ${ }^{68}$ By charming a good number of prominent heads of prestigious universities in America the project had grown into one requiring the setting up of an elaborate organisation that would require state funding. Kuo saw himself playing a significant role in this but he lacked full support from home. If such an organisation were to be set up, it would require a similar one in China where funds were lacking and the authorities to which he reported would need permission from another branch of the Ministry of Education, one which oversaw large scale developments along the lines Kuo was planning. ${ }^{69}$

Kuo hints in his autobiography that political backbiting might have led to the sabotaging of his plans and that some were alarmed that the doors to the influential in America were being opened to him (arrangements were being made, Kuo claimed, for him to meet Eleanor Roosevelt and Henry Morganthau Jr., Secretary to the Treasury). However he supplies no details of how he was to come to the attention of these prominent Americans. He may also have run afoul of the Chinese Minister for Education, Chen Li-fu, who with his brother Chen Kuo-fu was responsible for the

${ }^{66}$ Science, 1941 94, p.411

${ }^{67}$ Kuo to Thompson February 14th, 1942

${ }^{68}$ Confession. Ch. 8 "failure of a mission." 
"Central Club" -- a well placed clique within the KMT, which operated closely to Chiang Kai-shek -- and who was thought in some circles to be "more interested in indoctrinating students and faculties with political ideas than in promoting the type of education that the western democracies favour." ${ }^{70}$

In any event Kuo's role as emissary came to a sudden close. He remained in America on an extended university lecture tour during which, for once, he had no financial worries, alternating between lectures on psychology and on politics. He left for China in the fall of 1943.

\section{Exile in Hong Kong}

On the events in his life from this point on, his Confession is silent. In war torn China survival became the key issue. Kuo moved between Chungking, Shanghai and Canton (Guangzhou) where various members of his family were living. He fell ill with ulcers and, in the uncertainty of the immediate aftermath of the war, left for Hong Kong in 1946 with his third wife. ${ }^{71}$ He was 48 years old. He never worked formally in any fulltime job again. Instead he concentrated on writing his autobiography. This was to occupy him until the end of 1953 when he enlisted Tolman's help in trying to get a publisher. Tolman was initially cautious about possible costs, but also encouraging -- "It

\footnotetext{
69 Ibid.

${ }^{70}$ Ibid.

${ }^{71}$ Kuo's first marriage - arranged in his mid teens following the death of his mother -- was to produce five children, two of whom were born before Kuo went to Fu Tan and Berkeley, although only one - Kuo Yaoming - survived. After his return to Shanghai three more children were born -- Kuo Xiaoming, Ida Yu and Ai Fong (the last of whom died in early childhood). His second wife, who died in 1944, had one child, Alex. See also note 111.
} 
seems to us it is just the sort of document which should have appeal at the present moment. ${ }^{172}$ Shortly after this however, Basic Books rejected the manuscript. ${ }^{73}$

By the mid 50s, Kuo was thinking of employment again. His application to the University of Hong Kong was not successful in spite of Carmichael's support as referee. ${ }^{74}$ This did not deter him and he began to think in the late 50 s of returning to work in America and of working as a psychologist on social problems rather than continuing in the field of animal experimentation. ${ }^{75}$ Although by this time his wife was working quite successfully as a doctor in a large Kowloon hospital, his desire to leave Hong Kong in 1958 was over concern that his whereabouts had become known to both the Nationalists and the Communists. ${ }^{76}$ Following a suggestion from the Harvard anthropologist, Clyde Kluckhohn, whom Kuo briefly met when he briefly visited Hong Kong in 1958, Carmichael tried to secure funding for Kuo through the Ford Foundation. ${ }^{77}$ This proved unsuccessful. ${ }^{78}$ It was at this time that Kuo first expressed his interest in working on a book about the character of the Chinese. As he wrote to Carmichael, "The people of the West seem to have no way of understanding the Chinese mentality. This is chiefly responsible for so many tragic mistakes made by the American and British Governments in their dealings with both Nationalist and the Reds."79 This shifting interest coincided with an approach made to Carmichael by Robert Goodnow, a young social psychologist who was interested in going to Hong Kong to conduct

\footnotetext{
${ }^{72}$ Tolman to Kuo 29th January 1954

${ }^{73}$ Rosenthal to Macfarlane, 2nd July 1954

${ }^{74}$ The position at the University of Hong Kong was for a child psychologist in the education department. At that time psychology was still allied to philosophy

${ }^{75}$ Kuo to Carmichael 3rd November 1958

${ }^{76}$ Ibid.

${ }^{77}$ Kluckhohn to Carmichael, 6th February 1959

${ }^{78}$ Carmichael to Heald, 11th February 1959 Swayzee to Carmichael, 17th February 1959; Scott to Harper, 25th February 1959; Harper to Carmichael 2nd March 1959.

${ }^{79}$ Kuo to Carmichael, November 3rd 1958.
} 
research into perceptual functions and the formation of thinking concepts of the Chinese. The object of this research was to collect data on a Hong Kong sample to serve as a comparison to some Chinese American groups he had earlier studied at Cornell. Goodnow was sponsored by the Society for the Investigation of Human Ecology.

Carmichael hoped Kuo would co-operate with Goodnow in helping him obtain the data, in exchange for which Kuo might get some support from the Human Ecology Fund for his own research. ${ }^{80}$ Goodnow, through Carmichael, encouraged Kuo to make an application..$^{81}$ It was an opportune moment for them both. After Goodnow's arrival in Hong Kong Kuo helped him with contacts and publicised the purpose of his visit in the local paper. ${ }^{82} \mathrm{He}$ and his wife became friends of the Kuo family, and he wrote to the Executive Secretary of the Society, James Monroe, to get his approval for Kuo's grant. ${ }^{83}$ This was a significant departure from all of Kuo's previous research. Even as Carmichael was encouraging him to submit a proposal for research based upon his animal studies, ${ }^{84}$ Kuo already had in mind "to present to the West the true picture of the mind of the Chinese." ${ }^{15}$ It was to include an historical analysis of Chinese thought with a view to examining how the Chinese Communists had been successful at inculcating their ideas into the populace, and to speculate upon the outcome: whether they would "succeed in creating a new Chinese civilisation and a new Chinese mind". ${ }^{86}$

\footnotetext{
${ }^{80}$ Letters of Carmichael to Goodnow, and Kuo, March $18^{\text {th }}$, 1959; Carmichael to Goodnow, April $1^{\text {st }}, 1959$

${ }^{81}$ Goodnow to Carmichael, April 8th 1959; Carmichael to Kuo, April 29th 1959

${ }^{82}$ Reported in the Hong Kong Standard, $28^{\text {th }}$ September 1959, under a headline that ran, "Chinese 'more practical, rapid in thinking' than Americans."

${ }^{83}$ This grant was likely approved. In a letter he wrote to Kuo, Nov $7^{\text {th }} 1961$, Carmichael enquired about a grant renewal.

${ }^{84}$ Carmichael to Kuo April $29^{\text {th }} 1959$.

${ }^{85}$ Kuo to Carmichael May $20^{\text {th }} 1959$.

87 "Formation and Transformation of the mentality of the Chinese" was the title of the preliminary outline for a grant proposal (appendix to Kuo’s letter to Carmichael, May 20th 1959.) It was subsequently amended in the formal proposal submitted to the Society in October of that year to "A study of Certain
} 
This turned out to be a very productive time for Kuo again. As he set forth on his many interviews of Chinese émigrés to Hong Kong as part of the data gathering, he also decided to bring to publication his remaining work on animal fighting which was completed in the 1930s. With Carmichael's help these papers by-passed normal review procedures and were published in Carl Murchison's Journal of Genetic Psychology.

Appearing in 1960, these articles helped revive interest in Kuo, even though he had not devoted much time in the previous 15 years to furthering his scientific career. Within a couple of years of their appearance, significant interest began to be expressed in the value of Kuo's work.

A request came via Carmichael from Celia Stendler, the co-editor of a text of readings in child development, ${ }^{87}$ who wished to include two of these papers for her revised second edition. ${ }^{88}$ Only one appeared ${ }^{89}$ as evidence, on the Stendlers's view, that Kuo had shown "how animals can be immunized against innate antisocial tendencies by the appropriate control of environmental conditions" 90 which was something of a departure from Kuo's actual anti-instinctual view. Also among the requesters was Gilbert Gottlieb, who, impressed by what he read, decided to enlist support for Kuo to come to Washington in August 1960 where the International Congresses of Psychology and Zoology were being convened. ${ }^{91}$ An official letter of invitation followed, but Kuo, busy with his national character project, was not sure he would be able to attend and

Behavior Characteristics of the Chinese: their Historical Origin and their Bearings on the Communist Revolution."

${ }^{87}$ Stendler, C. and Stendler, F. Readings in child behavior and development. New York: Harcourt Brace Jovanovich 1964.

${ }^{88}$ Stendler to Carmichael May $21^{\text {st }} 1963$.

89 "Studies on the basic factors in animal fighting: VII. Inter-species co-existence in mammals," which originally appeared in 1960 in The Journal of Genetic Psychology, 97, 211-225.

${ }^{90}$ Stendler and Stendler op.cit. p. 8-9

${ }^{91}$ Gottlieb to Kuo, January $10^{\text {th }} 1963$ 
requested Gottlieb read his paper in his absence. ${ }^{92}$ As it turned out, finances became available from the organisers of both congresses and from the Human Ecology Fund that enabled Kuo to attend. ${ }^{93}$ In the meantime, Gottlieb applied for a grant to the National Science Foundation for funds to support the production of a film of Kuo's technique for studying duck embryos in vivo. Gottlieb wanted Kuo to be involved and applied for an allocation for two months work for him in the proposal. Aware of Kuo's earlier black and white film on the chick embryo, made with Carmichael, who, coincidentally, was asked by the Foundation to evaluate its scientific merit, ${ }^{94}$ Gottlieb argued that his film, to be shot in colour, would have educational value and might recoup costs through University distribution..$^{95}$ In support of his application, Gottlieb drew attention to a number of researchers who had "bolster[ed] their theoretical arguments against the genetic preformation theory of behaviour."196

Gottlieb also arranged an itinerary of lectures and meetings at other campuses, which thereby enabled Kuo to extend his stay in the USA by a couple of months. These engagements were to be in his field of comparative psychology, although Kuo also expressed interest in lecturing on national character. While working with Gottlieb he sought out other notable psychologists including J. R. Kantor and T. C. Schneirla.

Kuo also wrote to Carmichael at this time of a number of publishers being "keenly interested" in his "two proposed books on Chinese personality and China politically" and of his having been approached by a consulting editor for Random

\footnotetext{
${ }^{92}$ Kuo to David E. Davis, $10^{\text {th }}$ February 1963.

${ }^{93}$ Carmichael to Kuo, March $27^{\text {th }} 1963$.

${ }^{94}$ Henry S. Odbert, Program Director for Psychobiology of the National Science Foundation, to Carmichael, May $15^{\text {th }} 1963$.

95 The Penn State University Cinema Register, from which copy can be rented.
} 
House, ${ }^{97}$ to consider bringing his scientific work out in paperback. ${ }^{98}$ This latter suggestion eventually transpired and he published his ideas on comparative psychology, distilled from reflections on his early work, in 1967 in the Dynamics of Behavioural Development. ${ }^{99}$ But he also continued to work on his national character project, hoping to bring it out as a book. ${ }^{100}$ By 1966 the Cultural Revolution in China, masterminded by Mao, was well underway. Kuo's unpublished writings had anticipated this turn of events so that by January 1967 he was expressing reservations to Carmichael about publishing what were no longer forecasts but past events. ${ }^{101} \mathrm{He}$ did not entirely abandon the idea however, ${ }^{102}$ and continued to work on trying to produce an integrated text of his national character project alongside his autobiographical "Confession" to be known as "The Anatomy of Chinese Behaviour." 103 After his death in 1970, Academic Press expressed interest in it but, as it was critical of Mao Zedong, the editor decided not to pursue it as he "did not wish to harm relations with China."104 Kuo also published in Chinese an article of his "recollections" of being a behaviourist but, like the obituaries, they are devoid of any mention of his political activities and are not autobiographical at all. ${ }^{105}$

\footnotetext{
${ }^{96}$ G.Gottlieb, "Ontogeny of Embryonic behaviour in Aves: Motion Picture analysis". National Science Foundation Grant request B14676. The researchers' works cited included J.M. Hunt's book, Intelligence and Experience and papers by D.S. Lehrman and T.C. Schneirla.

${ }^{97}$ Joseph Stone of Vassar College.

${ }^{98}$ Kuo to Pearl and Leonard Carmichael, September $22^{\text {nd }} 1963$.

${ }^{99}$ The dynamics of behaviour development: an epigenetic view New York: Random House. (Subsequently republished by Plenum Press in 1976.)

${ }^{100}$ He had lectured to a group of American scholars working in Hong Kong on contemporary China. Kuo gave Carmichael a copy of the lecture entitled, "Psychological changes of the Chinese people" intending it for publication, but it remained unpublished.

${ }^{101}$ Kuo to Carmichael, January $31^{\text {st }} 1967$

102 Kuo to White Macpherson, 27th April, 1970

${ }^{103}$ The title turns up in a footnote in his 1968 article co-authored with Lam Yut-Hang, "Chinese religious behaviour and the deification of Mao Tse Tung. Psychological Record, 18 455-468.

${ }^{104}$ Gottlieb, personal communication Oct. 22, 1997

105 [Eng. translation: My recollections about behavioristic psychology.] Contemporary Philosophy and Social Sciences II n. 31958
} 


\section{A summing up}

The title of Kuo's unpublished autobiography is "Confession of a Chinese

Scientist". Yet the significance of the events sketched here raises the question, was he a scientist for China? From the available reports there is no doubting his intellectual acumen as a scholar, which set him apart from his contemporaries. He was fortunate in establishing an extraordinary reputation that preceded his return to his homeland after his doctoral studies. But his career did not follow the common path of Chinese graduates returning from abroad who entered academia and embarked upon lifelong teaching. ${ }^{106}$ He was by his own admission, "an uncompromising individualist"107 and, for some still to be accounted for fact, caught up in the larger political arena and allied to the Kuomintang cause. ${ }^{108}$ For much of the time from his return to China in 1923 until he left for good to settle in Hong Kong in $1946,{ }^{109}$ he was embroiled in high-level university administration and inevitably the politics that accompanied the running of a major university. This was politics with both a small and capital "p" as Kuo had to deal with uncooperative staff in his attempts to institute reform, while seeking the backing of the major political party of the day to cope with dissident students upset over what they perceived as weak Nationalist policies. Perhaps by virtue of his comfortable early life, ${ }^{110}$

\footnotetext{
${ }^{106}$ For an account of the problems and prospects facing returning students, see Jerome Chen, China and the West, Ch. 3

${ }^{107}$ Confession. Ch. 3 "Life among the Californians."

${ }^{108}$ While Kuo's own account talks at length if obliquely about his connections to various high profile Kuomintang personnel, it has proved impossible to corroborate his statements as a potentially valuable source of information, the Organisational Files of the Kuomintang, housed in the Second Historical archives in Nanjing, remain indefinitely closed.

${ }^{109}$ Except for a brief period between ' 27 and '32, and the four-year period he subsequently spent in America. However his own account and the relevant correspondence with Carmichael suggest he was still taking an active interest in matters of educational administration.

${ }^{110}$ He was born in 1898 into a wealthy merchant family of Chiu Chow origin, in a village near Swatow in Southeast China. His own mother had taken an active interest in his education, unlike his father who held
} 
he was too removed from ordinary everyday realities to deal with them effectively, and was more at home with policy planning. His attempts to reform the universities met with partial success. At the small (then private) University of Fudan in the 1920s, he brought changes to the forms of teaching and assessment. But at the bigger provincial university of Zhejiang in the mid 1930s, his insistence on a militaristic style of management led to many dismissals for minor infringements and his wreaking the ire of the student body, with which many of the teaching staff at the time were in sympathy. In spite of initial support from Chiang Kai-shek himself, ${ }^{111}$ the Education Ministry was eventually forced to accept Kuo's resignation as the movement to get rid of him swelled. ${ }^{112}$ His scientific reputation acquired in America helped him re-establish contacts there during a three and a half year period in the mid-1930s in which he revived his career as a researcher, but from his correspondence with Carmichael begun at this time, he appeared to be considering other options back home.

When Kuo did return to China in early 1940, in spite of his earlier difficulties at Zhejiang, he was appointed by the education ministry on a mission to Britain and America to gather support for Chinese students to further their studies in those countries when the war drew to a close. Ironically then, his connections in China led to him returning to America in what seemed like a preferred ambassadorial role. This was not ultimately successful as he stepped beyond the bounds of his mission. His activities upon his return to China in 1943 are not recorded, but in leaving in 1946 he appears to

the more traditional view of seeing Kuo as succeeding him in his business, and who would therefore need little other than an elementary schooling. When his mother and older sister died in a plague around 1911, it became his responsibility to assist his ailing father in the family business. Kuo agreed to this but persuaded his father to allow him to complete a secondary education as well. This may have contributed to his burgeoning confidence in as much as he began to assume an adult role very early in life. 
have been remarkably percipient in anticipating the outcome of the subsequent civil strife. He foresaw an inept government that was to allow a party for which he had little sympathy to overrun it and govern a China in which he no longer felt at home. Had the civil war ended in a victory for the Kuomintang, he might have become important in a way not anticipated by his reputation as an animal psychologist. He might have occupied a significant post in the educational sector and possibly taken psychology in China along a path very different from what occurred there in the 1950s.

In exile in the British crown colony of Hong Kong, Kuo felt a need to set down his thoughts about how and why the Communist victory had come about. The testimony of many refugees passing out of the Mainland through Hong Kong and the interviewing of many of their children set the tone for his project on Chinese national character, in which he saw the collective mind of China's youth under threat from a powerful Communist regime.

Kuo had done no scientific animal research since the 1940s although he kept caged birds on the balcony of his apartment throughout the fifties and sixties, and engaged in debates on nature and nurture with the occasional interested visitor. According to one, he appeared a lonely yet proud man who did not make contact with other psychologists in Hong Kong. ${ }^{113}$ By living in the vicinity of the Chinese border, reading local Chinese newspapers and attending to the accounts of his Chinese interviewees, he remained informed on China's affairs. The decades of the fifties and sixties in Hong Kong, with its periodic post-war uncertainties over its role vis a vis

\footnotetext{
${ }^{111}$ Chiang himself paid a visit to the campus on 22nd January 1936 and talked to both teachers and student representatives to try and get them to persuade the students to return to their studies. See Jia Jichu op.cit. p33ff.

${ }^{112}$ Ibid.

${ }^{113}$ Jacqueline Goodnow (personal communication).
} 
China, made living there uneasy for Chinese refugees. Yet he chose to remain, going neither to Taiwan, a favoured destination of exiled Nationalists, nor to the United States where he had strong academic connections. There was no firm financial possibility with the second option, so, as his wife's career flourished, there was perhaps the need to stay put while his children were being educated. His only support came from pursuing a project which, while of growing interest to him, was a radical departure from what his intellectual training had equipped him for. So why did he allow himself to be distracted by this project at a time when he could have worked at reviving his scientific career even before an invitation to return to a conference in America presented itself?

The question warrants closer scrutiny. Kuo's sponsor for the national character project - The Society for Human Ecology - as is now well documented ${ }^{114}$ was an organisation whose funding was underwritten by the CIA to promote behavioural research which could prove useful to an agency concerned about the psychological makeup of defectors and an enemy empowered with mysterious techniques of "brainwashing." The Society evolved out of the Cornell Medical College in 1955 under the directorship of Harold Wolf and operated until 1965, the period of the high point of the cold war. Many eminent psychologists received funding including Carl Rogers, Charles Osgood, George Kelly, B.F. Skinner, and Muzafer and Carolyn Sherif. Rogers and Kelly also served on its board (as did Carmichael). ${ }^{115}$ Much of the research undertaken by these and other psychologists had no espionage applications and many

\footnotetext{
${ }^{114}$ See John D. Marks The Search for the Manchurian Candidate: the CIA and Mind Control 1979 (reprinted 1991), also available at http://www.druglibrary.org/schaffer/lsd/marks.htm. See also Floyd Rudmin, "Historical notes from the dark side of cross-cultural psychology: research as espionage". Proceedings of the XXXII Cheiron conference, pp.92-102

${ }^{115}$ Carmichael was not a member of the board at the time he was encouraging Kuo to apply for funding. He became a member shortly after Kuo made an application but was not seemingly involved in the decision to award make a grant to Kuo.
} 
received grants not knowing the true source of the funding ${ }^{116}$ or the body's real purpose. ${ }^{117}$ The Agency had particular interests in Chinese subjects dating back to 1955 when they funded a rather bizarre study at Cornell set up in the hope of trying to convert 100 Chinese mainland refugees into becoming American spies. ${ }^{118}$ This was done under cover and a number of separate studies investigating aspects of Chinese character were carried out as a necessary preliminary. ${ }^{119}$

Against this background then, Kuo's national character study -- a radical departure from those in his field of comparative psychology -- can be seen in more dramatic relief. It may be, and perhaps is quite likely, that he knew nothing about the origins of this organisation, and was simply grateful for some moneys to pursue a pet interest in what had led the Chinese to embrace communism. Nonetheless, the decision of the Human Ecology Society to support his study might have been based on the view that its findings could prove valuable to the Agency -- even in ways not envisaged by Kuo himself. Kuo was interviewing many hundreds of Chinese immigrants flooding into HK in the late 1950s and many of these were ultimately hoping to get to the US, which might have had a more than passing interest in knowing whether any of them were potential spies. ${ }^{120}$

\footnotetext{
${ }^{116}$ Marks cites Carolyn Sherif as saying she was lied to by executive officer James Monroe about the source of the Society's money, claiming it came from New York doctors and Texas oil millionaires who gave it for tax purposes. (Marks, p.170)

${ }^{117}$ Rogers knew the true purpose of the organisation, but in the spirit of the times claimed "we really did regard Russia as the enemy... and were trying to do various things to ensure Russia did not get the upper hand." (Marks, p.168)

${ }^{118}$ Marks. p.160ff.

${ }^{119}$ This may have been the original study Robert Goodnow used for his HK comparisons, whether or not he knew the true identity and purpose of the sponsors of the research).

${ }^{120}$ Charles Osgood's cross-cultural semantic differential research into 31 different nations was funded by the Human Ecology Society (Rudmin, op.cit.). But the CIA and Human Ecology were not the only parties interested in what foreign nationals hostile to America were thinking. In 1955, the psychologist Hadley Cantril received an offer from Nelson Rockefeller, then special aide to President Eisenhower, to set up at Princeton where he had been working in the psychology department, the Institute for International Social
} 
Had Kuo known he was getting funds from an agency that was specifically dedicated to the anti-communistic cause, it might have appealed to his sense of himself as a "free" scholar. ${ }^{121}$ There is also his mysterious admission to Carmichael on one occasion that he had to "keep his promise to continue [his] little service to Uncle Sam." ${ }^{122}$ But the question of the granter's intention and the recipient's knowledge cannot be firmly decided one way or the other at this time because of lack of access to potential sources of relevant information. ${ }^{123}$

This former academic and university administrator with strong American connections, choosing to live in exile close to the country he had been previously well connected to, but whose current regime he resented, suggests he was ambivalent towards China. It seems he desired to run universities rather than simply teach and do research in them. He would likely have continued in this vein had the hostilities of the period gone differently, and he would have consigned his animal studies to the attic of history. The irony of his self-imposed exile is that it led to the renewal of his American acquaintances who encouraged the publication of Behavioural Dynamics, and revived his reputation as an animal psychologist, which continued posthumously. ${ }^{124}$

Research. The was done to enable him, along with his collaborator, Lloyd Free, to work full time on obtaining psychological data which could be "useful in the Government's attempt to influence the reactions of people in other nations to the United States and its policies." Cantril, H. (1967) The Human Dimension: Experiences in Policy Research. (p.17 and 129ff)

${ }^{121}$ He dedicated his Confession to "the Americans who fight to keep the intellectual light burning in the United States..." while claiming himself to be "a man who has personally witnessed the tragedy of intellectual blackout in the unfortunate land of China...".

${ }^{122}$ Kuo to Carmichael Sept $22^{\text {nd }} 1963$. The full sentence reads, "Besides, I have to keep my promise to continue my little service to Uncle Sam until next May or June." Kuo could have been alluding to completing the project for which the Human Ecology Society had funded him, but earlier in the letter he speaks of trying to get two books out, one on Chinese personality the other on China politically with no hint of working to a time frame or under any pressure to publish or withhold information.

${ }^{123}$ A request to the CIA for information on any files on Kuo was denied, and the appeal turned down on May $19^{\text {th }} 1999$ by Edward Cohen, Chairman of the Agency release panel. See also note 109 above.

${ }^{124}$ Ramona Rodriguez and Philip Rodkin's list of citations of Dynamics since publication, shows that since 1972 it has been cited between three and nine times a year in leading scientific journals every year till 1994 (Gottlieb, personal communication). 